\title{
CORRIGENDUM
}

\section{Multistability of a coherent spin ensemble in a semiconductor microcavity}

T. K. Paraïso, M. Wouters, Y. Léger, F. Mourier-Genoud and B. Deveaud-Plédran

Nature Materials 9, 655-660 (2010); published online: 4 July 2010; corrected after print: 19 November 2010.

In the version of this Article originally published, the $x$ axis of Figure $1 \mathrm{c}$ was incorrectly labelled ' $m e V$ ' instead of ' $\mu \mathrm{eV}$ '. This error has now been corrected in the HTML and PDF versions. 